\title{
Notes on Book-binding.
}

[Being the substanco of a paper read at the British Museum, Tuesday, Fully 18th, 1893, before the Sumuler School of the Library Association of the United Kingdom, by Cyril Davenport, F.S.A.]

\section{I.-USEFUL.}

FOLDING.-Before a book is bound the sheets on which it is printed are folded according to the manner in which the pages of letterpress are arranged upon them. In old books if the original sheet is printed over the entire surface, or if it is doubled once so as to contain two leaves, the book is described as a folio. If the sheet is again doubled it becomes a quarto, and if again, an octavo, and so on. These names however, in ordinary library notation, now that papers are made in very varying sizes, do not necessarily imply that the book is of any particular size, but the same terms, with various sub-divisions, are used by binders to indicate actual size in inches. Thus a book called demy 8vo measures 83 in. $\times 5 \frac{1}{2}$, one measuring $9 \frac{7}{2}$ in. $\times 6$ is called medium $8 \mathrm{vo}$, one measuring IIt $\times 88^{z}$ demy 4 to, $\& c$, and this quite apart from any question of folding. These divisions and sub-divisions of duo-decimos, octavos, quartos, \&rc., are to be found in what is known as a binder's rule, which is a necessary thing for any librarians in charge of binding work to have, because books are charged for according to their sizes. A sheet folded more than once requires cutting at the top and front edges, and here again I may advise librarians to be careful not to allow uncut books to get into the hands of the public, but to have them properly and carefully cut by a competent assistant with an ivory paper-cutter made in the proper shape.

Sewing.-Each section has now to be sewn with threads of silk or flax on to bands, the number of which should correspond to the size of the book. These bands are generally made of hemp, vellum, leather or tape, and the best sewing, now known as "flexible," is in principle the same as it always has been. In flexible sewing the thread at each band in succession is 
brought through the centre of section and passed round the band and in again at the same place. In sawn-in work the place of each band is marked by a saw-cut, into which the band fits, and the thread passes through the space between the outer edge of the band and the inner edge of the section. This is obviously a weaker form of sewing, as the backs of each section must be weakened by the cutting. Both kinds of sewing are done on a sewing-press by women. The threads should be finished off at the head and tail of the book on the headbands.

BoARDS. - When the sewing is finished the loose ends of the bands are "drawn in" to the boards. These boards, as their name implies, were originally of wood, but they were clumsy, and usually much eaten by worms, which afterwards attacked the book itself. Wooden boards were eventually succeeded by boards made of paper pressed and glued together.

Often leaves of books that are now of value were used to make these boards. A valuable collection of fragments printed by Caxton, which at one time formed the boards of a book is now in the British Museum.

Large books were generally kept on their sides, and to preserve them when in this position they frequently had bosses at the corners and centres, being probably kept from touching each other by a piece of cardboard placed between them. Also the title of the book is not uncommonly found written along the fore-edge of early printed books. Clasps are of great value for keeping the books well together, and in the case of smaller books that stand upright they also preserve the leaves from falling out, or unduly straining, the back of the binding.

The writing of the title of the book on the fore-edge may be considered the forerunner of the many forms of adornment of the fore-edge that have followed it, elaborate pictures painted on the fore-edge, titles and mottoes impressed in gold, heraldic devices, gauffring in gold and colours, of each of which there are innumerable old examples, up to the latest work that I know thus decorated, Mr. Loftie's Old Kensington. Now the edges of books are sprinkled, marbled, or gilded. In marbling old traditions arc still slavishly followed, and it is strange that some new departure or improvement is not made in this very curious and ancient art.

Covering.-The sewing of the back of the book and the junction of the bands with the boards are always protected with a covering, usually of leather. Sometimes this covering is only 
large enough to cover the back and a small portion of the boards, in which case it is known as a half binding. In the case of half bound books the ornamentation is generally of a slight character, but in the full bound books as we shall presently see, decoration can be carried to almost any length.

The leathers that are generally used for bindings are first of all morocco, which seems altogether to be the most valuable leather for the purpose. It was used early in the sixteenth century and has been in much favour from that time to the present day. It is prepared from goat skin and has the peculiar property of graining naturally under certain conditions of moisture and pressure. Deer skin was much used in England when the art of printing was first introduced, but its use seems to have been discontinued in the sixteenth century. It is white and has a rough surface and, so far as I know, is never decorated.

Calf has been used very largely at all times. The old calf was tanned, perhaps, with oak bark, and seems to be a better leather than the modern calf. All marblings and patterns produced on calf by the use of acids are bad, as they rot the leather, and indeed the process of tanning as now practised on this leather seems to render it delicate and easily destroyed. Vellum is prepared from calf and has many advantages. It does not hold dust, can be easily cleaned and looks well, but for lettering it almost needs a separate lettering-piece of a darker leather, which is never very advisable.

Pig-skin is very strong and durable. It is difficult to manage for small books, and has the reputation of being especially liable to ravages by worms. The leather known as "goat," which is used in the British Museum a good deal, is said to be the skin of a cross between a goat and a sheep. It is cheaper than morocco, looks well, and promises to last well.

Roan is prepared from Scotch sheep. It is a very useful leather for books not of much value. Parchment, basil, skiver and chamois are all prepared from roan. For very large books cowhide is useful, but it is apt to be of uneven thickness. Russia leather is not of much use for public libraries as it so soon becomes rotten.

Buckram is very valuable for books that are not likely to be much read, and so is cloth of good quality. Paper lasts well also; old music and old manuscripts are often found used as bindings on old books.

Old bindings should never be destroyed. If they are too bad 
to be mended they may be inlaid inside or outside the new boards, or entirely removed and put in a case by the side of the book to which they originally belonged. An old book should not be re-bound if it can possibly be avoided, as the old sewing is often quite good, and "pulling" an old book will often necessitate "making up". the back before it can be resewn, which is a difficult and expensive process.

Several forms of cases are used for old or valuable books. One is a cardboard slip case with gilt edges, which slips over the leaves of the book within the boards and preserves them admirably. This is especially useful for vellum books. Another kind is the simple slip-case, lined chamois, lettered on the back and covered in cloth or roan. Solander cases that shut with a clasp, and a case arranged to open front and back so that a book can be quite shown without touching it are also useful. Oblong embroidered covers were used to protect embroidered books while being read, and we sometimes find these books cnclosed in an embroidered bag. Leather satchels or "forels" were also used up to the fifteenth century for preserving valuable books. Of these forels there are two specimens in "cuir bouilli" upstairs in the Medizval Room, and a well-known one in the library of Trinity College, Dublin.

\section{II.-Ornamental.}

Now I will say a few words as to the general history of the ornamental styles and designs that are found in book bindings, leaving out, however, all mention of bindings of manuscripts, and oriental work, and only touching upon the representative forms found in England, France, Italy, Germany, and Holland.

Fiptennth Century.-All bindings that can be with certainty attributed to any particular binder are naturally of great interest, and from very early times now and then a binding is found with the name of its author in full. Thus we have in the Museum a book bound in 1475 by Jo. Richenbach, of Gyslingen, having both name and date impressed on the outer cover. It is pig skin, and is slightly coloured. There is another instance in the King's Library of an early binding about $147 \mathrm{I}$, that has the name of its binder, Conradus de Argentina, stamped on the binding. Some very fine cut and hand-tooled leather-work done in Germany also dates from the fifteenth century, and from the same country comes the first sign of gold used as a decorative adjunct in leather bindings. Koberger of Nuremberg in 1480 
used it, marking the titles of the works on the upper side of his bindings with gold, not applied in the same manner as at the present time, but most likely painted on with a brush.

In England the bindings of our early printed books are decorated, if at all, with small stamps impressed in blind;. Caxton and Rood of Oxford used small diamond shaped and oblong stamps, cut with designs of griffins, small animals, birds, \&c. Richard Pynson used a larger stamp, and early in the sixteenth century came a number of London binders who used stamps very similar to each other, having, however, as one of the differences personal to the binder himself, initials or a device.

Sixtennth Century.-One of these stamps has the Royal coat of arms, with supporters, as a central device, and the other the Tudor Rose surrounded by a ribbon bearing a motto. It is in the lower part of this second stamp that are found the initials or device of the binder. Those of $\mathrm{H}$. Jacobi, Nicholas Spierinck, R. Lant, John Reynes (who had several fine stamps, one especially curious, with the coat of arms of Jesus Christ), Julian Notary, Gerard Van Graten, and several others of this period having different initials on them, are well known. When the coat of arms of the city of London is found, it probably means that the binder was a member of the Stationers' Company.

In France also large and very fine stamps were used. One in the Museum, the central figure of which is St. Clothilde, is a particularly fine specimen. In Germany much stamped and coloured work was done in pig skin, generally with small stamps.

Traces of the influence of oriental taste are frequently met with, usually in the form of sunk panels gilded and coloured. It is certain that we owe a very great deal to the decorative influence of the East in bindings, especially on those coming from Italy. The bindings done at Rome, Florence and Venice during the sixteenth century are nearly always very good; among them must be specially noted those that were done for Jean Grolier de Servier, Viscount d'Aguisy, one of the first great book collectors. Many of his books were bound for him in Italy, and many more seem to have been done in France by Italian workmen. They are bound both in morocco and calf, and most of them have the legend, "Jo. Grolierii et amicorum" stamped upon them.

Grolier is credited with first using lettering pieces on books. The designs on his covers may have been designed by himseli or by Geofirey Tory, designer and printer to Francis 1. of France, 
but nothing certain is known. He also discontinued the use of wooden boards.

In Italy also beautiful bindings were made for Tommaso Maioli, bearing upon them the legend "T. Maioli et amicorum," some of them being specimens of the very valuable "cameo" bindings. A whole library bound in this style was inherited by Demetrio Canevari, physician to Pope Urban VIII., in 1590. The usual design on his books is Apollo driving on the waves.

J. A. De Thou, President of the Parliament of Paris, under Henri IV. of France, was also one of the great collectors of the sixteenth century. His books are usually bound in morocco or vellum, and are decorated with his coat of arms, sometimes alone, sometimes impaled with those of his first wife, Marie Barbançon, and sometimes with those of his second wife, Gasparde de la Chastre. Some of his books in light coloured morocco have a floral design painted upon them, a fashion that is very pretty, and might well be re-introduced in the present day. The library of De Thou was not finally dispersed till 1788 . The finest books in it were bound for him by Nicholas Eve.

The coloured enamel work done in this century in France, especially in Lyons and Paris, is worthy of note, as it was afterwards much copied by other countries, and is sometimes very cffective. The enamel, however, is apt to crack off.

French Royal bindings of the sixteenth century are much to be admired. Fine examples are known to have belonged to Francis I. and Henry II., Catherine de Medici, and Diane de Poictiers, who had a magnificent library at her chateau of Anet. She should not be forgotten by public librarians, as it was through her influence that an edict was issued that a copy on vellum, bound, of every book published with the King's permission, should be deposited in the Royal Library.

In England, again, fine work was done by Thomas Berthelet for Henry VIII. and Edward VI. Berthelet is also supposed to have been the first English binder to use gold outside a book, he gilded both on calf and vellum. In. England were bound also special books for Thomas Wotton (known as the "English Grolier," because he used on his book a similar legend to that of the great French collector), for Robert Dudley, Earl of Leicester, with his badge of the bear and ragged staff; the Earl of Arundel, with his badge of a white horse; Lord Lumley; and Archbishop Parker, who had bindings done at his own house.

Books in embroidered bindings reached their grcatest ex- 
cellence about the end of the 16th century. In England also was used the curious fashion of overlaying coloured satins on velvet bindings and stamping on them in gold. Examples of coloured work resembling that executed in France are also to be found.

Seventeenth Century.-At the beginning of the izth century much fine binding was executed for the reigning sovereigns. Royal bindings, indeed, about this period, both in France and England, may be taken as a kind of index to the best work produced. Fine work was done not only at London but also at Oxford and Cambridge. Inlaid or mosaic work, where small pieces of coloured leather are inlaid, is also found in English work of the century, and coloured work in enamels also. A peculiar form of decoration known as the "cottage" style, where part of the design is shaped like a roof is also first found during the I th century. The gold tooling on many English bindings of the "cottage" style is very delicate and pretty. In Scotland much good work was done. A peculiarity of Scottish design is the columnar form of the central part of the design. Several Scottish bindings have also fine doublures.

Embroidered work was much produced all through the 17th century, usually on books of a devotional character. The best designs occur on the smaller books, and among the larger work of this kind the best are perhaps the large heraldic designs worked for the Stuart kings, in gold and silver on crimson velvet.

Little Gidding is credited with having produced much of this embroidered work, and from that curious establishment came many of the fine bindings in velvet, stamped in gold and silver, some of which were done for Royalty itself. On several of these may be seen the stamp of a flying bird, supposed to be a pheasant, which was used by Cambridge binders, and this may perhaps be explained by the fact that Nicholas Ferrar had a practical binder sent from Cambridge to instruct his people at Little Gidding in the art of binding, and most likely this binder brought with him his Cambridge stamps.

The brothers Nicholas and Clovis Eve, in France, bound both in the 16 th and $17^{\text {th }}$ centuries. Their designs were very elaborate and beautiful, arabesque interlacings with the spaces filled up with foliated sprays, a style known as "Fanfare." Their bindings were either in morocco or vellum. 
Le Gascon, whose personality is still a mystery, decorated his books in a style known as "pointille," that is to say, instead of delicate lines he used minute dots placed in close juxtaposition. The effect is most rich and delicate. He also used mosaics of coloured leather. He had numerous imitators, the most successful being Magnus and Poncyn, both of Amsterdam. The tendency to overcrowd the ornament, which shows strongly in French work of the early part of this century, becomes much less marked towards its close.

From Italy, during the $17^{\text {th }}$ century, came many books adorned with a fan-like ornament in each corner. These books have usually also a circular form of decoration in the centre of the sides.

Eighteenth Century. - In England, early in the 18th century, fine books were bound by Eliot and Chapman for Robert Harley, Earl of Oxford, with very decorative borders, and for Thomas Hollis also several fine specimens of binding were made, decorated with curious emblematic tools. Roger Payne was a celebrated binder of the end of the century. His volumes are finished always with the greatest care and often have with them manuscript notes of the binding by Payne himself. They are usually bound in morocco or Russia leather. In connection with Roger Payne, who was liimself a great mender and restorer of books, are known the names of David Weir and his wife; Mrs. Weir, especially, was noted as a mender and restorer of old books. John Whitaker introduced a new style of decoration known as "Etruscan." The designs of this work were generally taken from Greek vases, and they were marked on the calf by means of acid. As a rule all stained calf is a mistake, because the acid invariably rots the leather. Edwards, of Halifax, covered books in vellum, rendered transparent by a process he invented, and painted on the under side.

In France, Padeloup le Jeune, who worked for Count d'Hoym, cxecuted some beautiful mosaic work, as also did J. A. Derome. Nicholas Derome, called Le Jeune, used a style imitative of lace, and known as "Dentelle," and is supposed to have been the first binder to put his name on a ticket in the book. Le Monnier, also a very successful inlayer, was another notable binder, but towards the end of the century the excellence of French work declincd.

Niseteenty Century. - During the rgth century in 
France and latterly in England, the best work is noticeable for its excellence of technique. Families of French binders are again found, and the traditions of good workshops kept up by successive masters. Bozerian, Thouvenin, Purgold, Trautz-Bauzonnet, with splendid doublures, Thibaron, Lortic, whose books are sometimes hardly thicker than a sheet of brown paper, Niedrte, Chambolle-DuruCape, and last but not least, Marius Michel, are all admirable exponents of the best French work of the century. Neither is England behindhand with good work. Early in the century come the followers of the style of Roger Payne, Walther, Hering, Kalthoeber, and others. Then Charles Lewis, who bound most of the books in the library of the Right Hon. Thomas Grenville; Francis Bedford, whose finish is little if at all inferior to the best French work; Rivierz, Tuckett, Zæhnsdorf, Mr. CobdenSanderson, and lastly the workmen of Messrs. Eyre and Spottiswoode, who do the large amount of ordinary but excellent work required for this library.

This, gentlemen, brings my rapid demonstration to a close, and it only remains for me to thank you very heartily for your kind attention.

Cyril Davenport.

Nots.-Specimens of each style, and of the books bound by, or for, each binder or collector mentioned, were shown furing the reading of the paper.

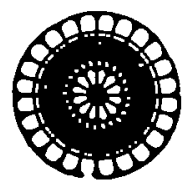

